УДК637.074:637.075

DOI: $10.15587 / 2313-8416.2014 .32252$

\title{
ВЛИЯНИЕ СОВРЕМЕННЫХ ТЕХНОЛОГИЙ ДОЕНИЯ И ПСИХРОТРОФНЫХ МИКРООРГАНИЗМОВ НА СОДЕРЖАНИЕ СВОБОДНЫХ ЖИРНЫХ КИСЛОТ В МОЛОКЕ
}

\author{
(C) А. Н. Бергилевич, А. Н. Марченко, О. А. Бергилевич
}

Установлено, что доение коров робототехникой в большей степени влияет на образование свободных жирных кислот (СЖК) в молоке, чем доение на АСД «Карусель». Среди всех исследуемых нами СЖК, наибольшую концентрацию в молоке составляли пальмитиновая, олеиновая и стеариновая жирные кислоты. Pseudomonas spp в молоке при холодильном хранении выделяют липазы, способствуюшие образованию СЖК. Добавление раствора $\mathrm{H}_{2} \mathrm{O}_{2} \kappa$ сырому молоку, приостанавливает образование бактериальных липаз

Ключевые слова: свободные жирные кислоты, доение робототехникой, холодильное хранение сырого молока, психротрофы, Pseudomonas spp

It was found that the milking of cows with robotics has a greater influence on formation of free fatty acids (FFA) in milk than automatic milking "Carousel." Among all researched FFA, the largest concentrations in milk were palmitic, oleic and stearic fatty acids. Pseudomonas spp in milk during refrigerated storage secrete lipase, promoting the FFA formation. Adding a solution of $\mathrm{H}_{2} \mathrm{O}_{2}$ to raw milk stops the formation of bacterial lipases

Keywords: free fatty acids, milking with robotics, refrigerated storage of raw milk, psyhrotrophs, Pseudomonas spp

\section{1. Введение}

Одной из основных задач производителей продовольственного сырья и пищевых продуктов является обеспечение их хорошего качества и безопасности для потребителей. Качество и безопасность молочных продуктов в большей степени зависит от молока-сырья. Если сырое молоко содержит контаминанты химической или биологической природы, то с большой долей вероятности эти контаминанты будут присутствовать в готовых молочных продуктах.

В святи с этим, в производстве безопасных и качественных молочных продуктов основной акцент делается на обеспечение получения такого сырого молока на молочных фермах, которое отвечало бы самым высоким современным требованиям. В этой связи, как в развитых странах, так и в Украине, для обеспечения получения высококачественного сырого молока, на фермах внедряются современные технологии доения и системы для обеспечения его качества и безопасности. Но, как свидетельствуют данные науки, не всегда современные технологии доения и системы безопасности дают гарантию получения высококачественного молока. Ученые постоянно проводят мониторинг показателей качества и безопасности сырого молока и выявляют разные факторы (новые и уже известные), которые в современных условиях его получения имеют отрицательное влияние на эти показатели. Так, в последнее время, в связи с активным внедрением на молочных фермах современных технологий доения, ученые стали изучать влияние доильной техники на показатели молока. Особенно это касается изучения влияния современных систем доения коров на жирнокислотный состав молока.

\section{2. Постановка проблемы}

Большинство исследователей указывают на то, что современные системы доения, незначительно влияют на качество молока. Но есть ученые, которые утверждает, что интенсивные технологии доения всё-таки влияют на показатели качества молока, в том числе, на содержание в нем свободных жирных кислот (СЖК)

Особое внимание ученых, в этом плане, было уделено влиянии доильных роботов на содержание СЖК в сыром молоке. Повышенная концентрация СЖК вызывает ухудшение технологических и органолептических свойств молока. Свободные жирные кислоты в молоке появляются вследствие гидролиза молочного жира. Как известно, молочный жир в молоке находится в виде жировых шариков диаметром 1-5 мкм, который защищен мембраной от эндогенного действия фермента липазы. При разрушении мембраны жировых шариков происходит гидролиз молочного жира липазами молока, что называется липолизом, при котором образуются свободные жирные кислоты [1]. Кроме того, липолиз молочного жира может быть как следствие образования липаз микроорганизмами молока, которые формируют его бактериальное загрязнение. Эти микроорганизмы характеризуют уровень гигиены и санитарии доения. Липазы микроорганизмов в большинстве имеют терморезистентные свойства и, таким образом, после пастеризации молока могут вызывать распад молочного жира с образованием СЖК. Следствием липолиза является появление таких пороков вкуса молока как прогорклый и салистый. Эти пороки молока устойчивы и могут привести к ухудшению качества молочных продуктов $[2,3]$. 
Итак, наличие свободных жирных кислот в сыром молоке коров является следствием распада жировых шариков под влиянием многих факторов, что приводит к ухудшению его органолептических и технологических свойств. Поэтому, одной из задач производителей молока является предупреждение появления СЖК в молоке. Этому должны способствовать научные исследования. В этом плане, важно определить степень влияния различных факторов на распад молочного жира и появление СЖК. Особенно важным, в настоящее время является изучение влияния на образование СЖК в молоке коров использования такой новой технологии доения, как доение роботом. Эта технология в настоящее время широко внедряется во многих странах мира. Технология доения роботом начала внедряться и в Украине. Вышеуказанное свидетельствует об актуальности изучения влияния современных технологий доения и холодостойких микроорганизмов гигиены и санитарии на образование СЖК в сыром молоке.

\section{3. Анализ литературных данных}

Молочный жир защищен от активности липазы, поскольку жировые шарики покрыты мембраной. Липолиз может быть инициированным через повреждения жировых шариков под механическим воздействием доильной системы при доении коров (вакуум, скорость движения потока молока, перемешивание молока, нагревание и т. д.). Кроме того, освобождение СЖК из молочного жира может происходить при увеличении кратности доения и при заболевании коров. Показатель СЖК зависит также от стадии лактации коровы, от длины молокопровода (активность липолиза тем выше или длиннее молокопровод) $[1,4]$.

Разрушение молочного жира является феноменом, который вызван такими энзимами как липазы: молочные липазы и/или бактериальные липазы, которые являются следствием бактериальной контаминации молока. Большинство липаз микроорганизмов терморезистеные и, поэтому в охлажденном молоке, а также в молоке после его пастеризации продолжают разрушать молочный жир, что приводит к ухудшению органолептических свойств, как самого молока, так и молочных продуктов [5-7].

В молоке содержится нативная и бактериальная липаза. Количество нативной липазы в нормальном молоке незначительно. Фермент связан главным образом с казеином и иммуноглобулинами (плазменная липаза), и лишь небольшая часть его (от 1 до $10 \%$ ) адсорбирована оболочками шариков жира (мембранная липаза). Липаза истинная (нативная) инактивируется при температуре $74-80{ }^{\circ} \mathrm{C}$, бактериальная - при 85-90 ${ }^{\circ} \mathrm{C}$. Нативная липаза теряет активность при температуре хранения молока от 0 до $5{ }^{\circ} \mathrm{C}$ через 48 ч, но при повышении титруемой кислотности молока и молочного жира ее активность возрастает. Температурные режимы обработки молока при производстве сыров способствуют инактивации нативной липазы, чего нельзя сказать о бактериальной липазе, отличающейся термостабильностью [8].

Итак, в зависимости от причины, вызывающей распад молочного жира в сыром молоке, липолиз разделяют на спонтанный и индуцированный. Спонтанный липолиз происходит при хранении молока в охлажденном состоянии под действием липаз молока и липаз микроорганизмов, которые попали в молоко. Индуцированный липолиз возникает при механическом разрушении оболочек жировых шариков, в процессе получения и обработки молока с одновременным активи-рованием липаз. Значительное разрушение оболочек жировых шариков и повышение активности липазы обусловлено интенсивной механической действием на молоко [3, 9].

Поскольку в сыром молоке есть нативная липаза, то при его получении и первичной обработке чтобы не допустить разрушения оболочек жировых шариков и активировании липазы, необходимо принимать меры чтобы механическое воздействие доильной техники и молочного оборудования было минимальным.

Помимо этого, необходимо уменьшать количество бактериальных липаз, которые могут поступать в молоко от маститных коров, а также продуцироваться различными микроорганизмами $[10,11]$. Несоответствующая действующим требованиям гигиена доения и содержания коров, а также нарушение условий хранения и обработки сырого молока могут провести к распространению нежелательных психротропных микроорганизмов, что может увеличить интенсивность липолиза. Низкий уровень гигиены доения коров, а также несоблюдение надлежащих условий хранения и первичной переработки сырого молока, может привести к увеличению количества нежелательных психрофильных и психротрофных микроорганизмов, вызывающих индуцированный липолиз. Увеличение количества СЖК также может быть следствием чрезмерного механического деформирования жировых шариков под действием вакуума в молочном оборудовании. Теплота механической энергии, а также само механическое воздействие, возникающее при движении молока в доильной установке и в молокопроводе, разрушает мембраны жировых шариков и тем самым освобождает СЖК из их связи в триглицеридах $[8,12]$.

Действие современных автоматизированных систем доения (АСД) также влияет на содержание СЖК, что выражается небольшим увеличением этого показателя, но это увеличение является статистически значимым относительно средней концентрации свободных жирных кислот $[3,5,13]$.

Особое внимание необходимо уделять современным доильным системам - робототехнике. Процесс доения - не просто забор молока от коровы, а это период тесного контакта между коровой и автоматизированной доильной машиной. В связи с этим как АСД, так и доильная робототехника (ДРТ) должны быть настроены таким образом, чтобы 
обеспечить безопасное для здоровья коровы доение и не причинять животному болевых ощущений. Отрицательное действие доильных машин на вымя коров вызывает его раздражение и мастит, что негативно отражается на показателях качества и безопасности молока. Первые АСД на фермах были введены в Нидерландах в 1992 году. С 2000 г. АСД стали признанными технологиями не только в Нидерландах но и в других европейских странах, а также Японии и Северной Америке. В конце 2009 г., по всему миру было более 8000 молочных ферм, на которых используются АСД [14-16].

В настоящее время кроме АСД, в передовых странах мира широко применяется роботизированная доильная техника. Особенно широко она внедрена фермерами в Западной Европе. Активно робототехнику фермеры начали внедрять в 90-х годах прошлого века. Так, уже до 1998 г. около 400 автоматизированных доильных роботов были установлены в следующих странах ЕС: Нидерланды (200), Германия (100), Дания (50), а во Франции, Бельгии и Великобритании (25) [17-19].

В настоящее время в Украине в Киевской области есть только одна молочная ферма, где используют два робота для доения 500 коров (Белоцерковский район, ЗАО «Терезино»).

Использование робототехники в процессе доения имеет много положительных моментов: роботы позволяют уменьшить количество обслуживающего персонала для доения коров. Управление ими осуществляется с помощью компьютерных программ. Роботы во время доения максимально приближены к физиологическим потребностям коровы. С помощью лазера робот идентифицирует каждую корову, определяет ее состояние здоровья и готовность к доению, диагностирует заболевания маститом, проводит обязательные гигиенические процедуры по подготовке вымени к доению и определяет основные показатели качества и безопасности молока (величина надоя, массовая доля жира, белка, содержание соматических клеток, общее количество микроорганизмов). Следует отметить, что при использовании роботов, доение на молочной ферме осуществляется постоянно - круглосуточно и корова сама определяет когда ей идти на дойку.

В зависимости от возраста коров, кратность доения одной особи в сутки может колебаться от 2-х до 6 раз. Примерно 60 коров могут обслуживаться одним роботом. Использование доильной робототехники (ДРТ) способствует увеличению производства молока и повышению эффективности его производства за счет уменьшения количества рабочей силы [20-22].

Проведением анализа данных литературы, можно констатировать, что в настоящее время существует относительно небольшое число исследований, касающихся изучения качества молока по содержанию СЖК в зависимости от технологии его получения. Значение СЖК в молоке может быть инструментом для контроля за влиянием автоматического доения коров, здоровья молочных коров, уровня санитарии и гигиены при доении коров на качество сырого молока. В связи с этим, исследования направленные на изучение действия различных факторов на содержание СЖК в молоке коров являются актуальными и имеют важное практическое значение.

\section{4. Цель и задачи исследований}

Целью данного исследования было изучение количественных и качественных значений СЖК в сыром молоке, полученного при различных системах доения (ДРТ и АСД) и под действием психротрофных микроорганизмов при хранении молока.

\section{обработка \\ 5. Экспериментальные данные и их}

Материалом для исследований были образцы сырого сборного молока коров, отобранные на молочных фермах ТДВ «Терезино» (роботизированная ферма) и ООО «Острийське» (доение на установке «Карусель») Белоцерковского р-на, Киевской обл. в течение 2014 г. Пробы отбирали из молочных танков от сборного молока, полученного в первые часы после его получения. При отборе проб молока были соблюдены правила асептики. Отобранные пробы молока исследовали на микробиологические показатели: на содержание психротрофных микроорганизмов общепринятыми стандартными методами в Белоцерковской государственной лаборатории ветеринарной медицины. Кроме этого в пробах молока исследовали содержание СЖК путем установления жиронкислотного спектра согласно ДСТУ ISO 55082001 «Жиры и масла животные и растительные. Анализ методом газовой хроматографии метиловых эфиров жирных кислот »

Хроматографический анализ жирных кислот выполнен на газовом хроматографе Trace Ultra3 пламенно-ионизационным детектором, на капиллярной колонке SP-2560 (Supelco). Предел обнаружения - 0,01 \%. Исследование жирных кислот выполнялось в Украинской лаборатории качества и безопасности продукции АПК (НУБИП). Было исследовано 25 проб молока с роботофермы и 25 из проб с фермы, где было доения на установке «Карусель». Каждый образец молока, который составлял 300 мл, мы делили на три части по 100 мл. Одна часть проб была подвергнута исследованию в течение 1-2-х часов после отбора на микробиологические показатели и исследованию на СЖК, а вторая - этим же исследованиям через 24 ч после отбора, а к третьей части проб добавляли раствор перекись водорода $0,02 \%$ для стабилизации образования СЖК и ее также исследовали на указанные показатели через 24 ч. Для сравнения результатов между группами проб молока проводили статистический анализ.

Проектная мощность роботизированной фермы ТДВ «Терезино» - 500 дойных коров, оборудованная двумя работами, средняя нагрузка на каждого робота - 65-70 коров в сутки. Порода - 
украинский черно-пестрая молочная и голштинская первой-третьей лактации. Суточный надой на фуражную корову - 28 кг, кратность доения 2,23,5 раз. В помещении фермы установлены селекционные ворота, которые имеют два входа для коров: один вход - для получения корма, а второй для процесса доения. Доения и кормление коров осуществляется круглосуточно. На ООО «ОСТРИЙСЬКЕ» содержится до 800 коров. Доения трех разовое на установке «Карусель». Результаты исследований содержания жирных кислот в сборном сыром молоке, отобранном сразу после его сбора при разных технологиях доения приведены в табл. 1.

Таблица 1

Результаты исследования СЖК в свежеотобранном охлажденном молоке

\begin{tabular}{|c|c|c|c|}
\hline \multirow{2}{*}{ Показатели } & \multirow{2}{*}{$\begin{array}{c}\text { Код жирной } \\
\text { кислоты }\end{array}$} & \multicolumn{2}{|c|}{ Результаты исследований } \\
\cline { 3 - 4 } & & \multicolumn{2}{|c|}{ Процент к общей сумме жирных кислот,\% } \\
\cline { 3 - 4 } & $\mathrm{C} 4: 0$ & $3,48 \pm 0,09$ & Доение АСД «Карусель» \\
\hline Масляная кислота & $\mathrm{C} 6: 0$ & $2,44 \pm 0,08$ & $3,01 \pm 0,01$ \\
\hline Капроновая кислота & $\mathrm{C} 8: 0$ & $1,53 \pm 0,11$ & $2,13 \pm 0,03$ \\
\hline Каприловая кислота & $\mathrm{C} 10: 0$ & $3,37 \pm 0,14$ & $2,24 \pm 0,12$ \\
\hline Каприновая кислота & $\mathrm{C} 10: 1$ & $0,40 \pm 0,02$ & $0,36 \pm 0,09$ \\
\hline Деценовая кислота & $\mathrm{C} 22: 0$ & $0,02 \pm 0,001$ & $0,04 \pm 0,01$ \\
\hline Бегеновая кислота насыщенная & $\mathrm{C} 12: 0$ & $3,73 \pm 0,15$ & $2,39 \pm 0,11$ \\
\hline Лауриновая кислота & $\mathrm{C} 14: 0$ & $11,20 \pm 0,23$ & $8,90 \pm 0,14$ \\
\hline Миристиновая кислота & $\mathrm{C} 14: 1$ & $1,06 \pm 0,08$ & $0,61 \pm 0,01$ \\
\hline Миристолеиновая кислота & $\mathrm{C} 15: 0$ & $1,24 \pm 0,04$ & $1,05 \pm 0,02$ \\
\hline Пентадекановая кислота & $\mathrm{C} 16: 1$ & $1,30 \pm 0,03$ & $1,06 \pm 0,032$ \\
\hline Пальмитолеиновая кислота & $\mathrm{C} 17: 0$ & $0,74 \pm 0,012$ & $0,56 \pm 0,01$ \\
\hline Гептадекановая кислота & $\mathrm{C} 18: 0$ & $10,23 \pm 0,15$ & $9,85 \pm 0,11$ \\
\hline Стеариновая кислота & $\mathrm{C} 16: 0$ & $27,3 \pm 0,21$ & $25,06 \pm 0,16$ \\
\hline Пальметиновая кислота & $\mathrm{C} 18: 1 \mathrm{n} 9 \mathrm{c}$ & $24,13 \pm 0,22$ & $21,05 \pm 0,18$ \\
\hline Олеиновая кислота & $\mathrm{C} 18: 2 \mathrm{n} 6 \mathrm{c}$ & $3,54 \pm 0,07$ & $2,75 \pm 0,05$ \\
\hline Линолевая кислота & $\mathrm{C} 18: 2 \mathrm{n} 6 \mathrm{t}$ & $0,29 \pm 0,04$ & $0,13 \pm 0,03$ \\
\hline Линолелаидиновая кислота & $\mathrm{C} 20: 0$ & $0,16 \pm 0,02$ & $0,12 \pm 0,01$ \\
\hline Арахиновая кислота & $\mathrm{C} 18: 3 \mathrm{n} 3 \mathrm{c}$ & $0,08 \pm 0,01$ & $0,07 \pm 0,01$ \\
\hline Линоленовая кислота & & & $0,87 \pm 0,04$ \\
\hline ненасыщенная & $\mathrm{C} 18: 1 \mathrm{n} 9 \mathrm{t}$ & $1,23 \pm 0,05$ & \\
\hline Элаидиновая кислота & \multicolumn{3}{|}{} \\
\hline
\end{tabular}

Как видно из данных табл. 1 в перечне исследованных СЖК в свежем молоке пребладают стеариновая, пальметиновая и олеиновая кислоты, среди которых наибольшее количество пальметиновой кислоты.

Мы обнаружили следующие тенденции относительно количества СЖК при использовании разных технологий доения: в свеженадоенном молоке все жирные кислоты были в большем количестве при доении ДРТ по сравнению с их количеством при доении на АСД. В минимальных количествах в молоке были установлены следующие СЖК: бегеновая, линоленовая, деценова и арахиновая кислоты.

Учитывая то, что на липолиз молочного жира кроме механического воздействия доильной техники, влияют микроорганизмы, которые попадают в молоко от животных, с доильного оборудования и с окружающей среды, мы изучили состав микрофлоры, которая может развиваться при холодильном хранении молока. Исследовали пробы молока в начале исследований и после хранения проб молока на протяжении 24 часов при температуре $4 \pm 1{ }^{\circ} \mathrm{C}$, было установлено, что количество холодолюбивых микроорганизмов составляло в среднем $14,5 \pm 2,1 \%$ по отношению к общему количеству микроорганизмов (КМАФАнМ). Содержание психрофильных было в среднем от

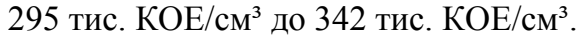

Следует отметить, что молоко, полученное при двух исследуемых доильных системах - АСД и ДРТ, было практически в одинаковой степени обсеменено исследуемыми микроорганизмами. Это можно объяснить тем, что фермы, на которых проводили исследования придерживаются надлежащей практики санитарии и гигиены при доении.

Протеолитические и липолитические свойства виделенных изолятов микроорганизмов представлены в табл. 2.

Как видно из табл. 2 липолитическую и протеолитическую активность проявляли такие микроорганизмы как Bacillus cereus, Pseudomonas и энтерококки, a $E$. coli- не проявляли этих свойств.

Мы исследовали пробы молока с содержанием Pseudomonas spp в количествах $1,2 \times 10^{3} \mathrm{KOE} / \mathrm{cm}^{3}-$ $1,5 \times 10^{3} \mathrm{KOE} / \mathrm{cm}^{3}$ на органолептические показатели в зависимости от срока хранения. Динамика изменений органолептических показателей 
охлажденного молока в зависимости от срока хранения, показана в табл. 3 .

Как видно из табл. 3, на протяжении 24 часов холодильного хранения в молоке сыром с содержанием Pseudomonas spp. были отмечено ухудшение таких органолептических показателей как цвет и запах молока.

Таким, образом мы подтвердили существующие данные про влияние психротрофной микрофлоры (Pseudomonas spp) на ухудшение органолептических показателей молока, которые были вызваны липолитическими и протееолитическими свойствами этого микроорганизма.

Нами изучены уровни СЖК после холодильного хранения проб молока (табл. 4)

Таблица 2

Протеолитические и липолитические свойства изолятов микроорганизмов, виделенных из проб молока сырого охладженного (после хранения на протяжении 24 часов)

\begin{tabular}{|c|c|c|}
\hline Изоляты & $\begin{array}{c}\text { Протеолитическа } \\
\text { я активность }\end{array}$ & $\begin{array}{c}\text { Липолитическа } \\
\text { я активность }\end{array}$ \\
\hline Lactococcus & + & - \\
\hline $\begin{array}{c}\text { Staphylococcu } \\
\text { s aureus }\end{array}$ & - & + \\
\hline E. coli & - & - \\
\hline $\begin{array}{c}\text { Bacillus } \\
\text { cereus }\end{array}$ & + & + \\
\hline Pseudomonas & + & + \\
\hline $\begin{array}{c}\text { Proteus } \\
\text { vulgaris }\end{array}$ & - & + \\
\hline Enterococcus & + & + \\
\hline
\end{tabular}

Таблица 3

Изменения органолептических показателей охлажденного молока в зависимости от срока хранения при температуре $4 \pm 1{ }^{\circ} \mathrm{C}$

\begin{tabular}{|c|c|c|c|}
\hline \multirow{2}{*}{$\begin{array}{c}\text { Пробы молока с } \\
\text { наличием: }\end{array}$} & \multicolumn{3}{|c|}{ Органолептические показатели (цвет, консистенция, запах) } \\
\hline & $\begin{array}{c}\text { В начале } \\
\text { исследования }\end{array}$ & Через 12 ч хранения & Через 24 ч хранения \\
\hline Pseudomonas & $\begin{array}{l}\text { Цвет белый, консис- } \\
\text { тенция однородная, } \\
\text { запах приятный, } \\
\text { свойственный } \\
\text { сырому охлажден- } \\
\text { ному молоку }\end{array}$ & $\begin{array}{c}\text { Цвет белый, слегка заметный } \\
\text { голубоватый оттенок, в слое } \\
\text { жира слегка заметны еди- } \\
\text { ничные трещины, запах и } \\
\text { консистенция свойственны } \\
\text { сырому охлажденному } \\
\text { молоку }\end{array}$ & $\begin{array}{c}\text { Цвет голубовато- белый, в слое } \\
\text { жира значительные трещины и } \\
\text { вздутия, запах молока кислотно- } \\
\text { спиртовый консистенция - } \\
\text { появление отдельных мелких } \\
\text { хлопьев, появление, горько- } \\
\text { ватого вкуса }\end{array}$ \\
\hline
\end{tabular}

Таблица 4

Результаты исследования СЖК в молоке после 24 часов его хранения при температуре $4 \pm 1{ }^{\circ} \mathrm{C}$

\begin{tabular}{|c|c|c|c|}
\hline \multirow[t]{3}{*}{ Показатели } & \multirow{3}{*}{$\begin{array}{c}\text { Код жирной } \\
\text { кислоты }\end{array}$} & \multicolumn{2}{|c|}{ Результаты исследований } \\
\hline & & \multicolumn{2}{|c|}{ Процент к общей сумме жирных кислот,\% } \\
\hline & & Доение роботом (ДРТ) & Доение АСД «Карусель» \\
\hline Масляная кислота & $\mathrm{C} 4: 0$ & $4,69 \pm 0,05$ & $4,28 \pm 0,13$ \\
\hline Капроновая кислота & C6:0 & $2,71 \pm 0,05$ & $2,37 \pm 0,05$ \\
\hline Каприловая кислота & $\mathrm{C} 8: 0$ & $1,70 \pm 0,13$ & $1,56 \pm 0,09$ \\
\hline Каприновая кислота & C10:0 & $3,82 \pm 0,07$ & $3,62 \pm 0,26$ \\
\hline Деценовая кислота & C10:1 & $0,69 \pm 0,04$ & $0,44 \pm 0,01$ \\
\hline $\begin{array}{l}\text { Бегеновая кислота } \\
\text { насыщенная }\end{array}$ & $\mathrm{C} 22: 0$ & $0,06 \pm 0,02$ & $0,08 \pm 0,01$ \\
\hline Лауриновая кислота & $\mathrm{C} 12: 0$ & $4,11 \pm 0,16$ & $4,02 \pm 0,19$ \\
\hline Миристиновая кислота & C14:0 & $12,68 \pm 0,26$ & $10,69 \pm 0,49$ \\
\hline Миристолеиновая кислота & C14:1 & $1,13 \pm 0,07$ & $0,94 \pm 0,03$ \\
\hline Пентадекановая кислота & C15:0 & $1,38 \pm 0,02$ & $1,17 \pm 0,02$ \\
\hline Пальмитолеиновая кислота & C16:1 & $1,33 \pm 0,02$ & $1,26 \pm 0,02$ \\
\hline Гептадекановая кислота & $\mathrm{C} 17: 0$ & $0,98 \pm 0,01$ & $0,71 \pm 0,06$ \\
\hline Стеариновая кислота & C18:0 & $12,07 \pm 0,12$ & $11,49 \pm 0,29$ \\
\hline Пальметиновая кислота & C16:0 & $32,78 \pm 1,19$ & $28,43 \pm 0,79$ \\
\hline Олеиновая кислота & $\mathrm{C} 18: \ln 9 \mathrm{c}$ & $30,01 \pm 1,21$ & $29,23 \pm 1,1$ \\
\hline Линолевая кислота & $\mathrm{C} 18: 2 \mathrm{n} 6 \mathrm{c}$ & $3,79 \pm 0,34$ & $3,70 \pm 0,17$ \\
\hline Линолелаидиновая кислота & $\mathrm{C} 18: 2 \mathrm{n} 6 \mathrm{t}$ & $0,32 \pm 0,02$ & $0,24 \pm 0,03$ \\
\hline Арахиновая кислота & $\mathrm{C} 20: 0$ & $0,19 \pm 0,01$ & $0,14 \pm 0,01$ \\
\hline $\begin{array}{l}\text { Линоленовая кислота } \\
\text { ненасыщенная }\end{array}$ & $\mathrm{C} 18: 3 \mathrm{n} 3 \mathrm{c}$ & $1,06 \pm 0,01$ & $0,82 \pm 0,01$ \\
\hline Элаидиновая кислота & $\mathrm{C} 18: \ln 9 \mathrm{t}$ & $1,36 \pm 0,02$ & $1,11 \pm 0,02$ \\
\hline
\end{tabular}


После 24-часового хранения сырого молока в охлажденном состоянии, количество СЖК в нем увеличилось по сравнению с их содержанием в начале опыта (молоко свежевыдоенное охлажденное). Как и в свежем охлажденном молоке, в молоке после хранения сохраняется тенденция более высоких уровней СЖК при использовании ДРТ по сравнению с молоком, полученным при помощи АСД «Карусель». Также, как и в свежем охлажденном молоке, уровни стеариновой, пальмитиновой и олеиновой кислот после 24-часового хранения молока, были наивысшими по сравнению с другими СЖК в этом опыте. Указанные три жирных кислоты после хранения молока были в большей концентрации по сравнению с их начальным уровнем в среднем на 20-24 \%. Остальные СЖК, также после хранения молока, были в более высоких уровнях по сравнению с их количеством до хранения молока, но это увеличение не было таким ощутимым как у стеариновой, пальмитиновой и олеиновой кислот.

Для упреждения развития микрофлоры молока и приостановления выделения ею энзимов, которые способствуют липолизу и образованию ЛЖК, мы добавляли в пробы молока раствор перекиси водорода. После холодильного хранения этих проб на протяжении 24 часов, мы определяли концентрации ЛЖК (табл. 5).

Таблица 5

Результаты исследования СЖК в молоке после 24 часов его хранения при температуре $4 \pm 1^{\circ} \mathrm{C}$ и добавления раствора $\mathrm{H}_{2} \mathrm{O}_{2}$.

\begin{tabular}{|l|c|c|c|}
\hline Показатели & \multirow{2}{*}{$\begin{array}{l}\text { Код жирной } \\
\text { кислоты }\end{array}$} & & \multicolumn{2}{|l|}{ Результаты исследований } \\
\cline { 3 - 4 } & & Процент к общей сумме жирных кислот, $\%$ \\
\cline { 3 - 4 } & & Доение роботом (ДРТ) & Доение АСД «Карусель» \\
\hline Масляная кислота & $\mathrm{C} 6: 0$ & $3,78 \pm 0,03$ & $3,61 \pm 0,01$ \\
\hline Капроновая кислота & $\mathrm{C} 8: 0$ & $2,79 \pm 0,04$ & $2,63 \pm 0,03$ \\
\hline Каприловая кислота & $\mathrm{C} 10: 0$ & $1,89 \pm 0,07$ & $1,54 \pm 0,07$ \\
\hline Каприновая кислота & $\mathrm{C} 10: 1$ & $3,39 \pm 0,15$ & $2,46 \pm 0,12$ \\
\hline Деценовая кислота & $\mathrm{C} 22: 0$ & $0,49 \pm 0,13$ & $0,36 \pm 0,07$ \\
\hline Бегеновая кислота насыщенная & $\mathrm{C} 12: 0$ & $0,03 \pm 0,01$ & $2,47 \pm 0,16$ \\
\hline Лауриновая кислота & $\mathrm{C} 14: 0$ & $3,85 \pm 0,14$ & $9,78 \pm 0,12$ \\
\hline Миристиновая кислота & $\mathrm{C} 14: 1$ & $11,45 \pm 0,13$ & $0,91 \pm 0,05$ \\
\hline Миристолеиновая кислота & $\mathrm{C} 15: 0$ & $1,12 \pm 0,09$ & $1,18 \pm 0,04$ \\
\hline Пентадекановая кислота & $\mathrm{C} 16: 1$ & $1,37 \pm 0,05$ & $1,16 \pm 0,03$ \\
\hline Пальмитолеиновая кислота & $\mathrm{C} 17: 0$ & $0,64 \pm 0,012$ & $0,49 \pm 0,01$ \\
\hline Гептадекановая кислота & $\mathrm{C} 18: 0$ & $10,53 \pm 0,37$ & $10,05 \pm 0,56$ \\
\hline Стеариновая кислота & $\mathrm{C} 16: 0$ & $27,96 \pm 1,23$ & $25,62 \pm 1,21$ \\
\hline Пальметиновая кислота & $\mathrm{C} 18: 1 \mathrm{n} 9 \mathrm{c}$ & $24,43 \pm 1,06$ & $21,58 \pm 1,04$ \\
\hline Олеиновая кислота & $\mathrm{C} 18: 2 \mathrm{n} 6 \mathrm{c}$ & $2,54 \pm 0,14$ & $2,15 \pm 0,09$ \\
\hline Линолевая кислота & $\mathrm{C} 18: 2 \mathrm{n} 6 \mathrm{t}$ & $0,20 \pm 0,03$ & $0,13 \pm 0,01$ \\
\hline Линолелаидиновая кислота & $\mathrm{C} 20: 0$ & $0,09 \pm 0,01$ & $0,07 \pm 0,01$ \\
\hline Арахиновая кислота & $\mathrm{C} 18: 3 \mathrm{n} 3 \mathrm{c}$ & $0,07 \pm 0,003$ & $0,05 \pm 0,001$ \\
\hline Линоленовая кислота ненасыщенная & $1,23 \pm 0,08$ & $0,87 \pm 0,04$ \\
\hline Элаидиновая кислота & $\mathrm{C} 18: 1 \mathrm{n} 9 \mathrm{t}$ & & \\
\hline
\end{tabular}

При добавлении раствора $\mathrm{H}_{2} \mathrm{O}_{2}$ к пробам сырого молока перед хранением мы отмечали его стабилизирующее действию по отношению к СЖК. Уровни всех СЖК в пробах молока с добавлением $\mathrm{H}_{2} \mathrm{O}_{2}$ после 24 часового хранения были значительно ниже, чем в пробах молока после хранения и без добавления $\mathrm{H}_{2} \mathrm{O}_{2}$. Необходимо отметить, что в данном исследовании мы отмечали так же, как и в предыдущих наших исследованиях, которые касались содержания СЖК в молоке, относительное повышенное содержание палметиновой, олеиновой, стеариновой жирных кислот. Все исследуемые жирные кислоты в молоке, к которому был добавлен раствор $\mathrm{H}_{2} \mathrm{O}_{2}$, при хранении увеличивались несущественно. Так, например, содержание палметиновой, олеиновой, стеариновой жирных кислот увеличилось в среднем на 1,2-2,9 \% по сравнению с их содержанием в свеженадоенном молоке. Также, в данном опыте, мы отмечали более высокие концентрации исследуемых СЖК при доении роботехникой по сравнению с доением на установке «Карусель».

\section{6. Выводы}

1. Из молока сырого охлажденного наиболее часто из всех психротрофных микроогранизмов выделялись Pseudomonas spp., которые обладали липолитической активностью

2. В пробах молока, которые были отобраны после его получения и охлаждения на ферме, содержание СЖК было более высоким при доении коров роботами, чем на автоматизированной доильной установке «Карусель». Среди всех 20-ти исследованных СЖК, наибольшие концентрации установлены относительно пальметиновой, олеиновой та стеариновой жирных кислот.

3. После 24-часового хранения молока при температуре $4 \pm 1{ }^{\circ} \mathrm{C}$ содержание всех исследуемых 
ВЖК повышалось, при этом в молоке, полученном при помощи роботов, увеличение количества СЖК происходило более интенсивно чем в молоке, полученном на доильной установке «Карусель». Содержание пальметиновой, олеиновой и стеариновой жирных кислот в молоке после хранения 24 ч повышалось в среднем на 20-24 \%.

4. Добавление раствора $\mathrm{H}_{2} \mathrm{O}_{2}$ к сырому охлажденному молоку перед хранением, стабилизировало интенсивность образования СЖК и их уровни повысились незначительно после хранения на протяжении 24 ч. Это свидетельствует про нейтрализацию бактериальных липаз в молоке раствором $\mathrm{H}_{2} \mathrm{O}_{2}$.

5. В большей степени повышение количества СЖК отмечали в молоке, полученном при помощи роботов, чем при доении на установке «Карусель».

6. После хранения молока с содержанием $\mathrm{H}_{2} \mathrm{O}_{2}$ на протяжении 24 ч при температуре $4 \pm 1{ }^{\circ} \mathrm{C}$ содержание пальметиновой, олеиновой и стеариновой жирных кислот повышалось в среднем на 1,2-2,9\%.

\section{Литература}

1. Ипема, А. Х. Свободные жирные кислоты; влияние частоты доения. [Текст] / А. Х. Ипема, Е. Шулинг // Симпозиум перспектив в автоматическом доении. Вагенинген, Нидерланды. - ЕААР Изд. 65, 1992. - С. 491496.

2. Klungel, G. H. The effect of the introduction of automatic milking on milk quality [Text] / G. H. Klungel, B. A. Slaghuis, H. Hogeveen // Journal of Dairy Science. -2000 - Vol. 83, Issue 9. - P. 1998-2003. doi: 10.3168/jds.s00220302(00)75077-6

3. Cartier, P. Spontaneous lipolysis in bovine milk: combined effects of nine characteristics in native milk [Text] / P. Cartier, Y. Chilliard // Journal of Dairy Science. - 1990. Vol. 73, Issue 5. - P. 1178-1186. doi: 10.3168/jds.s00220302(90)78780-2

4. Rasmussen, M. D. Milk quality on Danish farms with automatic milking systems [Text] / M. D. Rasmussen, M. Bjerring, P. Justesen, L. Jepsen // Journal of Dairy Science. 2002. - Vol. 85, Issue 11. - P. 2869-2878. doi: $10.3168 /$ jds.s0022-0302(02)74374-9

5. Escobar, G. J. Effect of mechanical treatment on the free fatty acid content of raw milk [Text] / G. J. Escobar, R. L. Bradley // Journal of Dairy Science. - 1990. - Vol. 73, Issue 8 - P. 2054-2060. doi: 10.3168/jds.s0022-0302(90)78884-4

6. Antonelli, M. L. Determination of free fatty acids and lipase activity in milk: quality and storage markers [Text] / M. L. Antonelli, R. Curini, D. Scricciolo, G. Vinci // Talanta. 2002. - Vol. 58, Issue 3. - P. 561-568. doi: 10.1016/s00399140(02)00324-7

7. Mikulova, M. Content of free fatty acids lipolytic bacteria and somatic cells in relation to milking technology [Text] / M. Mikulova // Journal of Agrobiology. - 2011. Vol. 28, Issue 1. - P. 49-54. doi: 10.2478/v10146-011-0005-8

8. Семприкова, П. Распространенность психротропных липолитических бактерий в сыром молоке коров [Текст] / П. Семприкова, М. Микулова // Чешский журнал животноводства. - 2009. - № 54 (2). - С. 65-73.

9. Флеминг, М. Г. Механические факторы, связанные с липолизом в коровьем молоке [Текст] / М. Г. Флеминг. - В IDF бюллетене № 118 Изменение вкуса молока и молочных продуктов из-за липолиза, 1980. - № 41-52.
10. De Koning, C. J. A. M. Milk Quality on Farms with an Automatic Milking System [Text] / C. J. A. M. De Koning, B. Slaghuis, Y. van der Vorst // Proceedings of the international symposium Automatic Milking, a better understanding, Wageningen Academic Publishers, Wageningen, the Netherlands, 2004. - P. 311-320.

11. Wiking, L. Impact of size distribution of milk fat globules on milk quality affected by pumping [Text] / L. Wiking, L. Bjrck, J. H. Nielsen. - Automatic Milking- a better understanding. Wageningen Academic Publishers, 2004. P. $348-356$

12. Foltys, V. Mesophilic and psychrotrophic aerobe sporulating microorganisms in raw cow's milk [Text] / V. Foltys, K. Kirchnerova // Central European Journal of Biology. - 2006. -

Vol. 1, Issue 4. - P. 545-560. doi: 10.2478/s11535-006-0037-Z

13. Pešek, M. Fatty acids and composition of their important groups in milk fat of Czech Pied cattle [Text] / M. Pešek, E. Samková, J. Špička // Czech J. Anim. Sci. - 2006. Vol. 51. - P. 181-188

14. Berentsen, P. B. M. Increasing the Revenues from Automatic Milking by Using Individual Variation in Milking Characteristics. Economical sensitivity of four main parameters defining the room for investment of AM-systems on dairy farms [Text] / P. B. M. Berentsen, B. Engel, C. J. A. M. De Koning, A. G. J.,M. Oude Lansink // Robotic Milking, Proceedings of the international symposium held in Lelystad, 2010. - P. 201-211.

15. Bijl, R. The Profitability of Automatic Milking on Dutch Dairy Farms [Text] / R. Bijl, S. R. Kooistra, H. Hogeveen // Journal of Dairy Science. - 2007. - Vol. 90, Issue 1. P. 239-248. doi: 10.3168/jds.s0022-0302(07)72625-5

16. Де Конинг, С. Д. А.М. Автоматическое доение: уровень мастерства в Европе и Северной Америке [Текст] / Де С. Д. А. М. Конинг Д., Роденбург. - В «Автоматическое доение - лучшее понимание. Academic Publishers, Вагенинген, Нидерланды, 2004. - С. 27-40.

17. Hink, P. Effects of husbandry systems on the efficiency and optimisation of robotic milking performance and management [Text] / P. Hink // International Symposium on Robotic Milking, Lelystad, The Netherlands, 2000. - P. 167-176.

18. Vorst, Y. Automatic milking systems and milk quality in three European countries [Text] / Y. Vorst, K. Koning // Proc. 1rst North American Conference on Robotic Milking, Toronto, Canada, 2002. - P. V1-V12.

19. Vegricht, J. Study of Using Automati c Milking Systems on Large Dairy Farms [Text] / J. Vegricht // Research In Agricultural Engineering. - 2002. - Vol. 48, Issue 1. - P. 1-6.

20. Барт, К. Оценка изменения электропроводности во время доения для обнаружения субклинического мастита у коров при доении с помощью робототехнических систем [Текст] / К. Барт, Р. Фишер, Х. Ворсторф // Проспекты Международного симпозиума по роботизированному доению. Лелистад, Нидерланды, 2000. - С. 89-96.

21. Klungel, G. H., Slaghuis, B. A., Hogeveen, H. The effect of the introduction of automatic milking systems on milk quality [Text] / G. H. Klungel, B. A. Slaghuis, H. Hogeveen // Journal of Dairy Science. - 2000. - Vol. 83, Issue 9. - P. 1998-

2003. doi: 10.3168/jds.s0022-0302(00)75077-6

22. Hantis-Zacharov, E. Culturable psychrotrophic bacteria communities in raw milk and their proteolytic and lipolytic traits [Text] / E. Hantis-Zacharov, M. Halpern // Applied and Environmental Microbiology. - 2007. - Vol. 73,

Issue 22. - P. 7162-7168. doi: 10.1128/aem.00866-07

\section{References}

1. Ipema, A. H., Schuiling, E. (1992). Free fatty acids; influence of milking frequency. in Proceedings of the 
Symposium Prospects for Automatic Milking EAAP Publ. 65, Wageningen, the Netherlands, 491-496.

2. Klungel, G. H., Slaghuis, B. A., Hogeveen, H. (2000). The effect of the introduction of automatic milking on milk quality. Journal of Dairy Science, 83 (9), 1998-2003. doi: 10.3168/jds.s0022-0302(00)75077-6

3. Cartier, P., Chilliard, Y. (1990). Spontaneous lipolysis in bovine milk: combined effects of nine characteristics in native milk. Journal of Dairy Science, 73 (5), 1178-1186. doi: 10.3168/jds.s0022-0302(90)78780-2

4. Rasmussen, M. D., Bjerring, M., Justesen, P., Jepsen, L. (2002). Milk quality on Danish farms with automatic milking systems. Journal of Dairy Science, 85 (11), 2869-2878. doi: 10.3168/jds.s0022-0302(02)74374-9

5. Escobar, G. J., Bradley, R. L. (1990). Effect of mechanical treatment on the free fatty acid content of raw milk. Journal of Dairy Science, 73 (8), 2054-2060. doi: 10.3168/jds.s0022-0302(90)78884-4

6. Antonelli, M. L., Curini, R., Scricciolo, D., Vinci, G. (2002). Determination of free fatty acids and lipase activity in milk: quality and storage markers. Talanta, 58 (3), 561-568. doi: 10.1016/s0039-9140(02)00324-7

7. Mikulova, M. (2011). Content of free fatty acids lipolytic bacteria and somatic cells in relation to milking technology. Journal of Agrobiology, 28 (1), 49-54.

doi: 10.2478/v10146-011-0005-8

8. Cempirkova, R., Mikulova, M. (2009). Incidence of psychrotrophic lipolytic bacteria in cow's raw milk. Czech J. Anim. Sci., 54 (2), 65-73.

9. Fleming, M. G. (1980). Mechanical factors associated with milk lipolysis in bovine milk. In IDF bulletin 118 Flavour impairment of milk and milk products due to lipolysis, 41-52.

10. De Koning, C. J. A. M., Slaghuis, B., van der Vorst, Y. (2004). Milk Quality on Farms with an Automatic Milking System. Proceedings of the international symposium Automatic Milking, a better understanding, Wageningen Academic Publishers, Wageningen, the Netherlands, 311-320.

11. Wiking, L., Bjrck, L., Nielsen, J. H. (2004). Impact of size distribution of milk fat globules on milk quality affected by pumping. Automatic Milking- a better understanding. Wageningen Academic Publishers, 348-356

12. Foltys, V., Kirchnerova, K. (2006). Mesophilic and psychrotrophic aerobe sporulating microorganisms in raw cow's milk. Central European Journal of Biology, 1 (4), 545-

560. doi: 10.2478/s11535-006-0037-z
13. Pešek, M., Samková, E., Špička, J. (2006). Fatty acids and composition of their important groups in milk fat of Czech Pied cattle. Czech J. Anim. Sci., 51, 181-188

14. Berentsen, P. B. M., Engel, B., De Koning, C. J. A. M., Oude Lansink, A. G. J. M. (2010). Increasing the Revenues from Automatic Milking by Using Individual Variation in Milking Characteristics. Economical sensitivity of four main parameters defining the room for investment of AM-systems on dairy farms, Robotic Milking, Proceedings of the international symposium held in Lelystad, 201-211.

15. Bijl, R., Kooistra, S. R., Hogeveen, H. (2007). The Profitability of Automatic Milking on Dutch Dairy Farms. Journal of Dairy Science, 90 (1), 239-248.

doi: 10.3168/jds.s0022-0302(07)72625-5

16. De Koning, C. J. A. M., Rodenburg, J. (2004). Automatic Milking: State of the Art in Europe and North America. Automatic milking - A better understanding, Wageningen Academic Publishers, Wageningen, the Netherlands, 27-40.

17. Hink, P. (2000). Effects of husbandry systems on the efficiency and optimisation of robotic milking performance and management. International Symposium on Robotic Milking, Lelystad, The Netherlands, 167-176.

18. Vorst, Y., Koning, K. (2002). Automatic milking systems and milk quality in three European countries. Proc. 1rst North American Conference on Robotic Milking, Toronto, Canada, V1-V12.

19. Vegricht, J. (2002). Study of Using Automati c Milking Systems on Large Dairy Farms. Research In Agricultural Engineering, 48 (1), 1-6.

20. Barth K., Fischer R., Worstorff H. (2000). Evaluation of variation in conductivity during milking to detect sub- clinical mastitis in cows milked by robotic systems. Proc. International Symposium on Robotic Milking, Lelystad, The Netherlands, 89-96.

21. Klungel, G. H., Slaghuis, B. A., Hogeveen, H. (2000). The effect of the introduction of automatic milking systems on milk quality. Journal of Dairy Science, 83 (9), 1998-2003. doi: 10.3168/jds.s0022-0302(00)75077-6

22. Hantis-Zacharov, E., Halpern, M. (2007). Culturable psychrotrophic bacteria communities in raw milk and their proteolytic and lipolytic traits. Applied and Environmental Microbiology, 73 (22), 7162-7168. doi: 10.1128/aem.00866-07

Дата надходження рукопису 30.11.2014

Бергилевич Александра Николаевна, доктор ветеринарных наук, профессор, кафедра технологии молока и мяса, Сумской национальнй аграрный университет, ул. Григория Кондратьева, 160, г. Сумы, Украина, 40021

E-mail: bergilevich@ukr.net

Марченко Андрей Николаевич, аспирант, Сумской национальный аграрный университет, ул. Григория Кондратьева, 160, г. Сумы, Украина, 40021

E-mail: bergilevich@ukr.net

Бергилевич Олег Александрович, старший врач ветеринарной медицины, Сумской государственной лаборатории ветеринарной медицины, ул. Якиры, 2, г. Сумы, Украина, 40021

E-mail: bergilevich@ukr.net 